\title{
Relationality and island studies in the Anthropocene
}

\author{
Jonathan Pugh \\ Newcastle University, UK \\ jonathan.pugh@,newcastle.ac.uk
}

\begin{abstract}
The island has become arguably one of the most emblematic figures of the Anthropocene. It is regularly invoked as exemplary of the changing stakes of our planet. This generates a crucially important role for island studies scholars; to explore, question, but now perhaps also trouble, some fundamental debates about islands in the Anthropocene. This paper picks up a particularly recurrent theme for island scholarship in recent decades-relationality and islands-and reorientates this within the stakes of the Anthropocene; discussing some implications for island studies, island ontology and resilience ethics.
\end{abstract}

Keywords: Anthropocene, islands, relationality, archipelagos, temporalities, indigenous, resilience.

https://doi.org/10.24043/isj.48

(C) 2018-Institute of Island Studies, University of Prince Edward Island, Canada.

\section{Introduction: the shifting stakes of the Anthropocene}

Over the past few decades there have been relational and archipelagic turns in island studies. A range of influential publications have drawn attention to the relational forces, and in particular the archipelagic thinking, which disrupts the static island form (Baldacchino, 2006; Brathwaite, 1999; DeLoughrey, 2007; Glissant, 1997a; Grydehøj et al., 2015; Hayward, 2012a; Pugh, 2013a; Stratford et al., 2011). As explored in many books, papers and conferences today, there are numerous reasons why we now talk about relational and archipelagic turns in island studies (Crane \& Fletcher, 2017; Grydehøj, 2017; Hay, 2016; Pugh, 2016; Roberts \& Stephens, 2017). But one reason that is rarely explicitly discussed, and which I take as my departure for this paper's concern with islands and relationality, is the waning of modernity and the associated rise in concern for non-modern frameworks of reasoning. For however we now date this - by the shift from linear to non-linear modelling, by saying that most people on the planet were never 'modern' anyway, or, as in this paper, by focusing upon the Anthropocene-it has become increasingly difficult to find security in modernity's old sanctums, binaries of humans/nature and neatly drawn horizons (Morton, 2013; 2016). Whilst life on planet earth has of course always been interconnected, boundarydisrespecting phenomenon like global warming, nuclear plumes, atmospheric and oceanic pollutants now really do bring home the point that modernity's neat compartmentalisations are increasingly untenable (Sloterdijk, 2009; Morton, 2013). We can no longer talk in terms of 'nature', 'raw material', 'wilderness', or other sealed off spaces 'just over there'.

Indeed, today the growing argument from a broad range of scientists is that planet earth has changed to such a degree that we now live in a new historical epoch called the Anthropocene. Distinguished from the Holecene, the term Anthropocene comes from the Ancient Greek word for human, 'anthropos'. As the website Welcome to the Anthropocene (2017) says, there is now "overwhelming global evidence that atmospheric, geologic, hydrologic, biospheric and other earth system processes" have been transformed by human actions. Saliently, the Anthropocene marks a "fundamental change in the relationship between humans and the Earth" (Lewis \& Maslin, 2015, p. 171). This increasingly "disputes 
the modernistic view of a strict division between nature and culture and reveals an Earth that is not a neutral background for human activity" (Verlaan, 2016, p. 1). For most leading contemporary philosophers of the Anthropocene, like Timothy Morton (2013, p. 15), the Anthropocene is overwhelmingly characterised as a new "Age of Asymmetry"-all life is now humbled within the vast spatiotemporal and multidimensional forces of a rapidly changing planet.

The overall aim of this paper is to think through the now recurrent theme of islands and relationality in island scholarship, and more explicitly reorientate this within the Anthropocene. Structurally, the next section of this paper begins by briefly reviewing some of the key aspects of the relational and archipelagic turns in island studies to date, before turning in detail to this central theme of islands and relationality in the Anthropocene. The last part of the paper considers how the concerns raised play into and through some critical contemporary debates for island resilience ethics.

\section{The relational and archipelagic turns in island studies}

Up until this point in island studies, the relational and archipelagic turns have tended to focus upon tracing out different relational mobilities, networks, constellations, aquapelagos, assemblages and island movements. Although in different ways, much of this work schematically falls under what is now often called 'thinking with the archipelago' (Pugh, 2013a, p. 9; Bongie, 1998; DeLoughrey, 2001; Glissant, 1997b). This is illustrated by, among other influential publications, Glissant's (1997a) Poetics of Relation; Bongie's (1998) Islands and Exiles; Brathwaite's (1999) tidalectics; DeLoughrey's (2007) Routes and Roots; Hau'ofa's (2008) We are the Ocean; Sheller's (2009) work on 'mobilities'; Stratford et al.'s (2011) 'archipelagic turn', and Hayward's (2012a) 'aquapelago'. In various ways in this literature, islands are constituted as "relational spaces" (Stratford, 2003, p. 495) that unsettle borders of land/sea, island/mainland, and problematize static tropes of island insularity, isolation, dependency and peripherality (Grydehøj \& Hayward, 2014; Pugh, 2005; 2013b; Rankin, 2017); all of which amounts to what I have called a 'relational turn' in island studies (Pugh, 2013a; 2016).

The relational and archipelagic turns have in particular emphasized the "power of crosscurrents and connections" (Stratford et al., 2011, p. 124) and foregrounded how we live in a world of relationality rather than 'static' islands of the world. A concern for relational island geographies is prevalent today in a wide range of geographical locations; for example, in research on the Caribbean (Dash, 2006; Pugh, 2016; Sheller, 2009), China (Hong, 2017), Chile (Hidalgo et al., 2015), Taiwan (Tsai, 2003; Lee et al., 2017), New Caledonia (Korson, 2017), New Zealand (Kearns \& Collins, 2016), Sardinia and Corsica (Farinelli, 2017), the Aegean (Karampela et al., 2017), Oceania (Farbotko et al., 2016), and the archipelagic Americas (Roberts \& Stephens, 2017), but also in research on archipelagic information systems (Vaitis et al., 2007), island literatures (Crane \& Fletcher, 2017; Redd, 2017; Graziadei et al., 2017), island diasporas (Martínez-San Miguel, 2014), and translocal social movements (Davis, 2017). In many different ways there has been a concerted effort to radically decentre notions of the static island and instead emphasize mobile, multiple and interconnected relational forms (Baldacchino, 2006; Clark \& Tsai 2009; Fletcher, 2011; Hau'ofa; 2008; Mountz, 2015; Sheller, 2009; Steinberg, 2001).

Such concerns have been given impetus by prominent statements from the President of the International Small Island Studies Association, Godfrey Baldacchino (2006, p. 10), who has set an important agenda for how islands are "part of complex and cross-cutting systems of regional and global interaction." As Elizabeth DeLoughrey (2001, p. 23), one of the seminal instigators of this way of thinking, says:

No island is an isolated isle [so instead] a system of archipelagraphy-that is, a historiography that considers chains of islands in fluctuating relationship 
to their surrounding seas, islands and continents-provides a more appropriate metaphor for reading island cultures.

Although brought together by these common concerns for the disruption of the static island, as regular readers of Island Studies Journal will know well, the relational and archipelagic turns have been developed in many different ways. One particularly appealing way has been through increasingly engaging and contributing to the contemporary 'oceanic turn' in the wider social sciences and humanities today; foregrounding island relationalities through an extending interest in oceanic materialities, currents, volumes, depths, mobilities, tides and swirls, but also watercraft, vessels and ships (Teaiwa, 2014; Blum, 2013; Bremner, 2016; DeLoughrey, 2001; Hayward, 2012a; Pugh, 2016; Rankin \& Collins, 2017; Steinberg, 2001; Steinberg \& Peters, 2015). From Hayward's (2012) 'aquapelago', to DeLoughrey's (2007) Routes and Roots, such debates now consistently bring to the fore how oceans are not a simple medium of transport between islands, or from A to B, but rather material, social, political and affective spaces themselves that play into island relationalities (DeLoughrey, 2007; Hayward, 2012a; Pugh, 2016; Steinberg \& Peters, 2015). These kinds of connections are perhaps most obviously drawn out in contemporary research on shifting ice-sheets (Riquet, 2016; Steinberg \& Kristoffersen, 2017), but are also powerfully brought into play in all sorts of other innovative ways in island studies today. For example, in Roberts and Stephens (2017, p. 1) seminal idea of the 'archipelagic Americas', the Americas "are clearly not confined to the islands and waters that have been appropriated by the United States" but span through multifaceted colonial, material, affective and political relations into the Caribbean, Indonesia, and many other island and ocean regions of the world that disrupt neat boundaries of island/sea.

Indeed, the reach of these relational and archipelagic turns today, both within, and increasingly beyond, the traditional realms of island studies would now need a book to be comprehensively reviewed. Like many readers of Island Studies Journal, I find it both interesting and rewarding when today I see them playing through academic disciplines that at first sight seem far removed from island studies, and from each other but which-from contemporary political theory, to the creative arts, and architecture-increasingly engage with them.

The central question for this paper is: what do the shifting stakes of the Anthropocene mean for how we think through relationality and islands? Here we can initially begin with an influential paper for the relational and archipelagic turns in island studies: Phil Hayward's (2012b) 'The constitution of assemblages and the aquapelagality of Haida Gwaai'. For Hayward (2012b, p. 3), it is the new materialism of Jane Bennett's (2010) Vibrant Matter which is "particularly pertinment" for his development of the concept of the aquapelago. The philosophical tradition of new materialism is taken as key to understanding the materialities of human and more-than-human assemblages involving islands, oceans, rivers and interweaving liquid relationalities in flux. Developing the aquapelago concept in part as a response to the perceived lack of engagement with oceans, rivers and liquid entanglements in Stratford et al.'s (2011) conceptualisation of the archipelago, for Hayward (2012b, p. 3) "the humans who constitute aquapelagos through their engagements with terrestrial and aquatic spaces are (necessarily) engaged in interaction with what Bennett describes as the "vibrant matter' of the environment, characterised by the 'vitality' of various non-human things." New materialism and the affective relations of more-than-human entanglements are key to unlocking these island and watery relationalities, and here Hayward (2012b, p. 3) is also interested in situating the aquapelago directly within debates about the Anthropocene:

My proposition of the aquapelago as a concept and focus is intended to facilitate comprehension of Anthropocene impacts on interrelated aquatic and land environments and of the impact on and responses of nonhuman actants. 
Indeed, such developments now illustrate how island studies scholars are shifting to embed their thinking about islands and relationality more firmly in the stakes of the Anthropocene:

There can be no Island Studies that doesn't have consideration of Anthropocene impacts as a major element of its field and of its individual instantiations. While islands may have seemed relatively fixed entities when the discipline began aggregating in the 1980s it has become apparent that islands are increasingly in flux. Aquapelagic relations are shifting and reconfiguring at rapid rates. The land areas, elevations and general viability of islands to support particular populations and their relationship to mobile expanses of waters and the nature of subsurface biomasses are in flux and require constant attention. To be an islander is, increasingly, to live in flux. To be an Island Studies scholar is, increasingly, to be scholar of flux. (Hayward, 2018)

But in this paper, as I think through relationality and islands in the Anthropocene, I take a different approach from new materialism; and, indeed, from many other prominent approaches associated with the relational and archipelagic turns today. This is not to say that I completely reject these developments which still have importance, but that I am interested in exploring some new approaches for how we can think through relationality and islands in the Anthropocene: both in terms of general shifts in tone of debate, and specifically in terms of definable island ontology and consequences for ethics.

To start with, we can bring about the more general tonal shift of this paper by simply stating that, in the Anthropocene, islands are much more obviously humbled within the vast multidimensional forces of a rapidly changing planet. Here Clark and Yusoff (2017, p. 16) make clear the contrast to previous approaches:

Whereas the political traction of the more-than-human in new materialist ontologies has tended to be bound up with relations of interconnectedness, reciprocity and mutual affectivity between human and nonhuman actors, [by contrast, in the Anthropocene, we can now develop a more explicit sense of] a before, a beneath, a beyond to the human presence that draws our attention to other modes of relating.

During the last years of the $20^{\text {th }}$ century much of the focus in philosophy, the social sciences and humanities was concerned with opening up the spatial; and in earlier developments like assemblage theory, (de)territorialisations, rhizomes, actor network theory, new materialism, mobilities and the spatial turn, the concern was for changing our understanding of the human at the ontological level - in particular to disrupt the human/nature divide and better develop concerns for more-than-human entanglements (Chandler, 2018; Pugh et al., 2009; Grove \& Pugh; 2015; Pugh \& Grove, 2017). We see this played out in the relational and archipelagic turns to date; for example, in Hayward's aquapelago. As concern about the changing environment has gathered apace, these debates have not only importantly reflected but have also sought to better incorporate and keep track of rapidly changing global conditions. Yet, whereas these developments have tended to forward an ethics of ecophilsophical embeddness, for Morton (2013, p. 181) it is the vast multidimensionalites of Anthropocene which have finally removed "humans from the center of their conceptual world." Indeed, realising that all islands today already exist within the multidimensional forces of global warming, means that even as we embed ourselves down in the affective materialities of local fluxes and flows, higher dimensions of nonlocality now increasingly force their way into our consciousness. Global warming is thus not only about being in the midst of a disorientating environmental crisis in time and space, but also about this profoundly disorientating corrosion of time and space as well (Danowski \& De Castro, 2017, p. 18). Psychological space has become more coextensive with ecological space in the Anthropocene; not only in terms of the collapse of 
modernity's nature/culture binary foregrounded by previous relational thinking, but also in terms of how the multidimensional forces of the Anthropocene accentuate a before, beyond and beneath to the human presence and other modes of sensing relation (Clark \& Yusoff, 2017; Chakrabarty, 2009; Danowski \& De Castro, 2017; Stengers, 2015).

In 1784 James Watt invented the steam engine and from then on "carbon from coalfired industries began to be deposited worldwide" with resulting global warming (Morton, 2013, p. 4). In 1945 the first nuclear bomb was exploded in New Mexico, and since then there have been at least "2,056 nuclear test explosions" (Arms Control Association, 2017), "with attendant worldwide fallout easily identifiable in the chemostratigraphic record" (Zalasiewicz et al., 2015, p. 197). These global and boundary-disrepecting phenomena, which play out through vast, multiple, spatiotemporal dimensions, require new ways of thinking through relationality and islands. We actually already glimpse this coming shift in the inspirational work of one of the seminal thinkers for island studies to date: Édouard Glissant's (1997a) Poetics of Relation. Towards the end of Glissant's massively influential book the tone begins to shift from the more explicitly Deleuzian-inspired concerns of the earlier chapters, to the latter parts when Glissant (1997a, p. 203) explicitly says "the circle [of Relation] opens up once more, at the same time that it builds in volume." Here reflecting upon the fallout of the nuclear plume from Chernobyl, Glissant (1997a, p. 203), explains:

\begin{abstract}
What was the infinite detour taken by this nuclear catastrophe, whose worldwide repercussions were felt among the destitute as well as among the well-to-do, in savanna villages, probably, just as much as in skyscrapers, and which consequently fed the most passively experienced commonplaces in the planetary consciousness, that led it also to be condensed into what seemed to be an involuntary poem, through which it happened that the world could speak to us?
\end{abstract}

This paragraph is not easily understood through the tropes of rhizomic relations, (de)terriorialisations, mobilities, new materialism, networks and assemblages that have dominated debate to date. It is instead more explicitly about the afterprint of the nuclear plume, and therefore better framed and ontologised in terms of phasing within vast multidimensional forces beyond our grasp. Humans and non-humans within these zones of relation on a small island would be dealing with the local imprint of the totality of this nuclear plume, playing out through trillions of temporal, as well as spatial, dimensions: some immediate, others lasting thousands of years. Like global warming, they would be dealing with their phasing within what Morton (2013) calls 'hyperobjects' of massive proportions. By the end of the Poetics of Relation, Glissant's (1997a, p. 203) approach starts to "open up" into this new tone; and, I contend, hints productively at some new stakes for island and archipelagic studies.

\title{
Islands in the Anthropocene: island ontology and islands phasing within vastly interweaving temporalities
}

As noted, to date the relational and archipelagic turns in island studies have done much to complement socio-geographical thinking about how 'place' is not merely a backdrop or container, but rather constructed out of dynamically interweaving spatial relations (Pugh, 2013a). But although this means that the spatial has been interrogated to a great extent, and in particular how space-time is colonialized by imperialist narratives, we have given less attention to time itself. When we do think about time, we tend to focus upon how islands have changed over history, or how island histories, "like maps," "name, order, and confer meanings to space" (Okihiro, 2010, p. 745). We do not tend to situate the island itself within 
multiple unfolding temporalities, extending island ontology into these vast multidimensional relations too; a concern which the Anthropocene now brings to the fore.

The Anthropocene forces us to think big because its violence does not unfold all at once, but rather through massively interweaving temporal dimensions-some extremely slow and taking place over hundreds of millennia, others having a much more sudden impact and violence (Morton, 2013). Global warming, for example, humbles islands within different overlapping temporalities - from the extractive capitalism which pumps $\mathrm{CO}_{2}$ into the atmosphere and is rapidly changing the global climate, to the thousands of years it takes carbon emissions to dissolve in the oceans, to the immediate violence of hurricanes. Global warming puts oceans and islands into new phases that may be smoother temporal transitions for some entities than others. Some will adjust and thrive, others will survive less well over time, or completely die out. Indeed, if we could somehow stand back far enough, outside of space and time itself, we would see global warming as this weird multidimensional object unfolding through trillions of interweaving temporalities (Morton, 2013). Global warming is an enormous hyperobject which is transforming the planet not only because it spreads spatially, but also because it unfolds through these many different temporal dimensions as well (Morton, 2013).

A concern with interweaving temporalities is invoked by island studies scholars, such as Fleury and Raoulx's (2017, pp. 7-8) recent paper on Mont Saint-Michel Bay, north-western France:

In physical-material terms, the landscape of this area has changed during different periods due to the opposing processes of sedimentation and erosion. At the end of the last Ice Age, the rise of sea levels led to processes of submergence, shaping islands and islets of various sizes from high areas of otherwise inundated land. The present day island of Guernsey was isolated around 7000 B.C (Patton, 1995), followed by the other Channel Islands; Jersey, the largest one, being the last to be detached from the continental mainland, around 4000 B.C. (Cunliffe, 1995). Closer to the continent, islets, rocks and reefs follow each other until they reach the three small rocky islands dominating the bottom corner of the Gulf: Mont Saint-Michel (originally named Mont Tombe), Tombelaine and Mont-Dol [...] At the opposite of the time scale, a twice-a-day tidal movement that is amongst the highest in the world brings sedimentary deposits that have gradually filled the bay. As a result, the bay is also known for both the speed of its tidal flows and the quicksands. The erratic course of the three rivers flowing into the bay, the Couesnon, Sée and Sélune, also contribute to shape an ever-changing landscape of water and sand.

This passage usefully illustrates how multiple temporalities unfold to shape island geographies. The Anthropocene encourages this kind of thinking, but it now also pushes, intensifies and reorientates thinking about relationality and islands in new ways too. Being on an island is about experiencing the various phases of the sun, moon, tides, oceans and stars, rising sea levels, sedimentary desposits, and rivers. But today, as I now discuss, the crisis of the Anthropocene much more obviously brings our attention to many other multidimensional forces, and how islands phase within the interweaving temporalities of a transforming planet.

"Rippling with time," trillions of entities come into zones of relation on an island and "tease other objects into their sphere of influence" (Morton, 2013, p. 63). There is the deep time of the stars and constellations observed from the island hundreds of thousands of light years away as these are mediated by the energies of urban light pollution. There is the nonlinear time of global climate change brought about by the earth's ellipsis around the sun and massive global carbon emissions, as these phase into relation with complex island ecosystems that also blur neat binaries of humans/nature. There is the slow decompositional time of carbon decomposing in the oceans surrounding the island, coming from from extractive capitalist 
industries on the island itself and elsewhere. There are the sudden violent times of El Niño events, monsoons or hurricanes, perhaps immediately hitting this island itself, or elsewhere in the globe, but which nevertheless impacts upon the temporal rythms of an island's economic, social and cultural systems.

Taken into high enough dimensions then, this all suggests that the island in its totality can now be framed as something like a total "phase space," which "is the set of all the possible states of a system" (Morton, 2013, p. 71). All entities only ever glimpse patches of this total phase space in their brief existence, whilst the vast totality of island relation is withdrawn; simultaneously exerting a downward pressure upon entities as they phase into relation. We hear the island in the trees, oceans, rocks, surfaces, oceans, etc.; but there is also this humbling ontological "rift" between the totality of island relation and us (Morton, 2012, p. 236). Only certain phases of island time will be observed by humans, just as only certain unfolding temporalities will be experienced by turtles, rock, crabs, or internet cables. Ontologically, it is precisely this intimacy of phasing into certain zones of relation, and not others, which makes the island itself-as a total 'object'-impossible to grasp in its totality. It is our "phenomenological enmeshment in zones, [which] is the very thing that prevents me from grasping the zone as solid and predictable" (Morton, 2013, p. 144). Like the imprinted footsteps on a beach washed away by the tide, what we call the island present is a shifting, ambiguous phasing within a totality beyond our grasp (Morton, 2013).

Reconfiguring relationality and islands in these terms of phasing within relation means that the island is not only deviant from the grasping categories of modernity because it can be understood through more-than-human assemblages, actor-network theory or new materialism (Morton, 2016). Ontolologically, the island as a total object is also deviant precisely because phasing and acclimatising to relation "means to approach, then diminish, from a certain fullness," the totality of which is nevertheless withdrawn (Morton, 2013, p. 74). Today, the changing stakes of the Anthropocene encourage us to frame relationality and islands in these new terms of phasing within relation and in terms of how entities that are massively distributed in time, like global warming, nuclear plumes and hurricanes, exert downward pressure on short-lived entities, causing interference patterns where entities get caught up in intersecting temporalities (Glissant, 1997a; Morton, 2013).

\section{Reconsidering island ontology, edges and boundaries}

Here we start to move from the general shifting tone of this paper towards a more precise island ontology. The perennial question of island boundaries and edges in particular will never be far from island studies scholars minds, as we reorientate the stakes of island studies in the Anthropocene. Today in island studies there is much debate concerning whether island edges are 'fluid' or 'fixed' (Hay, 2006; 2016; Stratford et al., 2011; Hayward, 2012b; Pugh, 2013). 'Fluid' can seem more generous, progressive and disruptive of static island geography. Whilst 'fixed' can give a heightened sense of phenomenological experience (Hay, 2006; 2016). Thinking about islands in terms of multiple, unfolding temporalities and the richness of relationality in the Anthropocene raises some new questions for island ontology too. In further elaborating these here it is useful to briefly employ examples redolent of fractal theory which are familiar to island studies scholars:

The bay, when examined within a closer frame, is shown to contain many subbays, and each subbay, when examined within a still closer frame, contains many subsubbays, and the sub-subbays further resolve into a sub-sub-subbays in an infinite regress of recurisively smaller analytic frames (Roberts \& Stephens, 2017, p. 26). 
And again, from Morton (2016, pp. 71-72):

If you look at the coastline of an island from space, you will see something fairly regular-perhaps it's rather triangular. When you look close up, say from a hang glider, you will see all kinds of curves and folds that you didn't see from space. And when you crawl around the surface of the coastline as an ant about three millimeters long, you will find something very different again — not just impressionistically different, but extensionally different: the circumference will be a different length. Indeed there may be circumstances - ways of measuring that island - that cause its circumference to be infinite. This is rather like what happens when you examine something like a Koch Curve, the fractal shape in which triangles are populated with smaller versions of themselves to infinity. One ends up with a shape that is bounded yet infinite.

I am interested in these two quotes because they also engage island ontology in a different way from the dominant relational and archipelagic turns in island studies to date, and help us further clarify the stakes of this paper. In a different way from new materialism, mobilities, assemblage and actor-network theory-inspired debates, the above two quotes concerning bays and fractals also tell us that relationality is too rich, too intense, to grasp in the way of modern frameworks of reasoning; but this time precisely because of the ontological withdrawnness of the island itself (Morton, 2013; 2016). Islands are reconfigured as 'TARDIS'like (Morton, 2016, p. 71), containing more on the 'inside' than the outside. Islands are 'hyperobjective spaces' (Roberts \& Stephens, 2017, p. 24; Morton, 2016), where the totality of the island as an object is greater than anything which can be experienced phenomenologically. The key take home point in terms of island ontology involves the humbling ontological rift, which cannot be located anywhere in ontically given space-time, and which reflects the gap between the island in its totality, on the one hand, and the intimacies of interweaving zones of relation on the other (Morton, 2016). Indeed, the above examples of fractal geometry tell us this precisely - there are bays within bays, which exist all the way down to infinity, and we cannot grasp this by reference to phenomenological experience alone. We come to realise that there really is a before, beneath and beyond to sensing island relation that remains fundamentally and ontologically withdrawn. We see that the island not only exceeds through the excesses of networked relations, mobilities, and vibrant materialities, but also at this other fundmental level of island ontology too.

Whilst such debates might seem detached from the crisis of the Anthropocene, it is important to stress that they are not mere philosophical musings. Agree with Morton, or not, as Blasdel (2017) says, Morton does capture something of the affective pull of the Anthropcoene - that sense of all life now existing within multidimensional relations which are simply beyond our grasp; something which, as just explained, has important implications for island ontology.

Here, very much explicitly tied up into all this sense of relation existing before, beneath and beyond, are the rapidly developing transformative logics concerned with how we sense island relations and hyperobjects like global warming in the Anthropocene. As Morton (2013, p. 140) says, "the fact that we need devices such as computers and Geiger counters to see hyperobjects that will define our future, is humbling in the same way Copernicus and Galileo brought humans down to earth by insisting that the universe was not rotating around us." We are now living at a time when there is a massive interest in extending beyond and into the richness of relationality in the Anthropocene in new ways, and through different modes of sensing: from the transformative logics of climate change big data, 'real-time' computer modelling, and newly emergent algorithms, to hundreds of orbiting satellites circulating around the planet, contemporary social media, and a growing incorporation of indigenous 
island communities' frameworks of reasoning into resilience paradigms, to name but a few prominent examples. From many quarters, there is this increasing realisation that sensing relation in the way of the old moderns is not enough, and precisely because relationality in the Anthropocene is beyond their grasp.

\section{Sensing island relationalities in the Anthropocene: the changing stakes of digital revolutions and data machines}

Recent years have seen a more obvious proliferating interest in the transformative logics of all sorts of data processes and sensing techniques that both grapple with and rework the unfolding temporalities of the Anthropocene. They have also, however, increasingly seen books with titles like The Vast Machine (Edwards, 2010) and The Stack (Bratton, 2016). In The Stack, Benjamin Bratton (2016, p. 5) examines how our planet is being slowly transformed by an "accidental megastructure" which has evolved through massive collections of data and governance; from the data collected through island colonialism, the expeditions of Wallace and Darwin, to Google, iPhones, climate science big data, social media, spatial data mining, algorithms, and the material production of the infrastructures necessary to sustain and generate them. "These technologies align, layer by layer, into something like a vast, if also incomplete, pervasive if also irregular, software and hardware Stack" (Bratton, 2016, p. 5). The Stack is therefore beyond older tropes of globalisation and more firmly implicated in debates about the Anthropocene. For example, further teasing together spheres of relation and reconfiguring island temporalities in the Anthropocene are the sensing techniques of hundreds of orbiting satelites, GPS systems, and climate change big data, perhaps also drones, algorithms, and Twitter feeds, and so forth. The temporal rythms of island life are generated as these phase into zones of relation - algorithms associated with climate change time the island in one way; nuclear plumes and big data on degrading carbon and sea level rises time the island in other ways too.

This means that The Stack is not only calculative; it is geological, sociological, economic, chemical and geopolitical. As an article in The Guardian reads "if you own a mobile, it's probably held together by tin from the Indonesian island of Bangka" (Hodal, 2017). But even if islands are not directly involved in new data production processes, in the Anthropocene it is increasingly difficult to undertake island studies in complete isolation from them. Not only does the rise of digital technology demand massive energy use and therefore directly contribute to the changing conditions of the Anthropocene within which islands are implicated, but the transformative logics of digital technology today are playing a key role in how islands and relationality, and the unfolding temporalities of the Anthropocene, are reworked, understood and engaged.

In Jakarta, called by some 'the city of the Anthropocene', the NGO Peta Jakarta now employs social media and Twitter to develop sophisticated real-time flood mapping for the city (Chandler, 2017, p. 113; Peta Jakarta, 2018). Today, "approximately 60 per cent of Pacific Islanders now have access to a mobile phone and this figure continues to climb" and with "growing social media presence in the region, Facebook and, to some degree, Twitter have become sources of information for journalists during natural disasters" (Papoutsaki et al., 2016). In the Caribbean, particularly post-2017 hurricane devastation, the use of big data analytics is now often seen as key to dealing with increased and intensified hurricanes (Whyte, 2017). Some of these developments will challenge the idea of islanders as "passive recipients of telecommunication technologies and its development" whilst others will raise questions of how data mining takes place, who controls and operates data, and how its transformative logics play out in different island geopolitical, sociological and economic contexts (Hayakawa, 2016, p. 179). "Today synthetic computation expands what is sensed, measured, calculated, communicated, stored and worked on" (Bratton, 2016, p. 88). Digital technologies from 
bitcoin in the Cayman Islands, to the selling of internet domains on Tuvalu, implicate islands in new digital processes. But even where they do not, the multiple, interweaving and contesting transformative logics of digital revolutions play an increasingly important role in measuring, sensing and reframing the island in the Anthropocene.

Famously, for Virilio, the world has become a tragic consequence of its appearance in digital images of itself (Depardon \& Virilio, 2008). We are all being reduced, shrunken and eaten up by digitised time. But, in practice, island studies scholars now need to do more to unpack the contextual nuances of contemporary digital revolutions and their transformative logics as these pertain to different island contexts. As Springer et al. (2017) say in Reverse Halluccinations in the Archipelago, an innovative text which I believe will become seminal for island studies, we cannot ignore such debates. These authors rightly argue for the "relevance" of the Stack "for a contemporary consideration of the concept of the island as such":

Bratton's layer of address within the Stack identifies various means by which data (and their socio-spatial consequences) are measured and classified as a means for their governance. Contrary to popular belief in a free and fluid internet, legibility-cumaddressability is even more consequential as the morphology of sovereignty increasingly exhibits dematerializations, virtualizations, physical assertions, and material instantiations, that is, as politics are simultaneously rendered through a transformative logic of software (Springer et al., 2017, p. 18).

The confines of a journal article do not permit detailed discussion here, but the salient point is that even as islands exist within the Anthropocene in different ways, today islands are measured, captured and sensed by a proliferating range of software and data machines and associated transformative logics — from big data stored by companies often thousands of miles away from the island itself, to Twitter and social media, and the incorporation of indigenous islanders' frameworks of reasoning into large international development programmes. These cannot be separated from experience of the Anthropocene and associated concerns with the extension and intensification of relationality as such. Building upon legacies of colonialism and island histories, some of the data processes which feed into our understanding of islands today are much older than others, and they often work in tension with each other; but, to a greater or lesser extent, they come into zones of relation which frame island life and the vastly interweaving spatiotemporalities of the Anthropocene.

\section{Relationality and island resilience ethics in the Anthropocene}

The proliferation of new sensing techniques is of importance to island studies in the Anthropocene. The more we realise that relationality is complex and interconnected, but also beyond our grasp in the way of the old moderns, the more we seem to open ourselves out to new and innovative ways of sensing relation. The waning confidence in modernity is today both accompanied and stimulated by a proliferation of new approaches: complex big data and algorithms associated with climate change, new techniques for mapping the complexity of ecological systems, but also a particular growing interest in 'non-modern' and 'indigenous' ways of sensing the environment and relation (see below). As the island ecologist Beatte Ratter (2012, p. 83) saliently notes, today the focus in island ecology is changing "from linear development to non-linear behaviour." This is necessary, as we come to realise that older modern frameworks of reasoning are no longer up to the task of grasping the sheer complexity of relation in the Anthropocene (Mycoo, 2017). Indeed, this is also precisely what the growth of the 'risk society' means: the idea that relationality has become too rich, too intense, to control; so that even as complexity "corrodes our ability to make firm decisions in the 
present," we need to extend and diversify the range of measuring techniques, modes of computation and technologies (Morton, 2013, p. 140).

Such important developments further play out and through the changing nature of ethics in the Anthropocene; and in particular 'resilience' as a key trope in island studies today. A leading resilience scholar, Neil Adger (2000, p. 347), defines resilience as "the ability of groups or communities to cope with external stresses and disturbances as a result of social, political and environmental change." It is due to their specific perceived vulnerabilities, including small size, isolation and limited resources, that over the 1980s and 1990s the acronym SIDS (Small Island Developing States) emerged as emblematic of the need for these resilience debates more generally. Only a year after Time Magazine heralded 'resilience' as the new buzzword for our times, the United Nations designated 2014 as the 'international year' of SIDS. More recent years have seen the relationship between resilience and islands gathering apace. In 2017, the Presidency of the United Nations Climate Change Conference, where resilience discourses are prominent, was not held by the USA or UK, but by Fiji.

Today, one reflection of the limits of late modernism in the Anthropocene is the increasing emphasis on 'non-modern' and 'indigenous' knowledge in island resilience debates. A celebration of indigeneity is reflected in international policy in the work of the Intergovernmental Panel on Climate Change (IPCC) where islands figure particularly prominently. Indigenous knowledge was acknowledged in the Fourth Assessment Report as "an invaluable basis for developing adaptation and natural resource management strategies in response to environmental and other forms of change" (Parry et al., 2007, 15.6.1). Recognition was included as a guiding principle for the Cancun Adaptation Framework adopted at the 2010 United Nations Framework Convention on Climate Change Conference (UNFCCC, 2010). The IPCC's Working Group II contribution to the Fifth Assessment Report also includes local and traditional knowledge as distinct topics within Chapter 12 on human security (Nakashima et al., 2012). As Chandler and Reid (2018, pp. 9-10) summarise the shifting stakes:

The reason why indigenous ways of being are feted is for the specific attributes of coping with natural or environmental problems, which are seen to evade the grasp of modern science and technology. When nature was seen as a passive object open to modernist understanding and appropriate, indigenous ways of being were seen to lack history and agency. Today, the tables are turned ... The collapse of the nature/culture divide and the focus on the previously ignored liveliness, power and agency of natural forces, previously thought to be passive, innate and lacking in agency, has transformed the understanding of indigeneity. The indigenous are the anthropocenealogists of non-modern ontology; they can teach the moderns how to see the non-human differently.

Yet, as Elizebeth Povinelli (2016, p. 56) now rightly cautions, this more generally reflects how today's understanding of indigenous knowledge reduces indigenous analytics to local or cultural knowledge of relations, extending the sphere of being at home in the world, enabling late liberal governmentality to "saturate Being with familiar and reassuring qualities." Here, the island itself is never given its due, never appreciated in all its rich, vast, multiplicity and potentiality noted above, but is instead flattened and reduced. Keeping this firmly within island studies, I maintain that it is important to never stray too far from Pete Hay's (2006) seminal Island Studies Journal paper on phenomenology and islands. For all the above discussions that might lead readers to conclude otherwise, I nevertheless feel Hay is always a key point of reference; because he constantly provokes us on the point of distinctive island experiences (see also Baldacchino, 2006; Pugh, 2016; 2017). By contrast, today far too much contemporary resilience literature paints a reductive and romanticised picture of islands and 
islanders as somehow 'naturally attuned' to the complex and unpredictable forces of the Anthropocene. Nadarajah and Grydehøj (2016, p. 437) have called "for an island studies perspective on decolonization." Today, similarly, there is a need for a more nunaced island studies' perspective concerning the figure of the island in the Anthropocene.

When we consider the longer history of island studies, something rather odd, and perhaps unintentional, is happening to the figure of the island in the Anthropocene. As island scholars know only too well, the island has often been something of a placeholder for wider Western projections and anxieties (Gillis, 2004, p. 1). Indeed, as Luo and Grydehøj (2017) say, island romanticisation is not just a 'Western' phenomenon, although it may be a phenomenon associated with certain large continental perspectives more generally. Our times of global environmental insecurity are no different. In the Anthropocene, the island and indigenous island community is once again being "naturalized" (Papetti, 2017); but this time by being saturated with vulnerability, adaptation and resilience ethics. Islanders are of course often resilient, but resilience ethics can also become a way of externalising the problem of the Anthropocene onto island communities themselves. Resilience ethics tend to throw the violence of the Anthropocene back onto the island community, telling islanders that they need to draw upon their rich community resources in order to survive.

Debates about the hurricane-ravaged Caribbean in 2017 demonstrated time again how reducing islands to 'resilience' can be a rather impoverished political horizon for island life. As a New York Times article by Giusti-Cordero (2017) says, 'In Puerto Rico, we invented resilience'. Through slavery, oppression and capitalist exploitation, these islands had little choice. But being merely resilient also offers little transformative weight when it comes to the massive political might of the industrially polluting nations of the world in the Anthropocene, and the violence of international capitalist exploitation that prevents islands from recovering effectively from environmental disasters (Kelman, 2014; Papetti, 2017; Pugh, 2005; 2013b; 2017; Reid, 2017). Indeed, there is now one particularly famous quote which appeared on placards scattered around New Orleans after Hurricane Katrina, attributed to Tracie Washington of the Louisiana Justice Institute, which said: "Stop calling me resilient. Because every time you say, 'Oh, they're resilient' that means you can do something else to me" (Nola Defender, 2017).

As Papetti (2017) says about Pacific islands:

In order to go at the root causes of climate change we have to analyze the sociopolitical and economic dynamics generating global warming. The threats to the Pacific Islands populations are the consequences of centuries of competition, striving for surplus value extraction and profit maximization: in one word, centuries of capitalism. In fact, it is not only the resource (fossil fuel) in itself that increases the earth temperature, but the fact that it has been (over)used by capitalist societies as primary source of energy in order to subdue both nature and humans.

Ilan Kelman (2014, p. 120) similarly asks the salient question: "are SIDS an example of climate change's rhetoric detracting from dealing with wider development problems?" Is focusing upon climate change deflecting attention "away from underlying political conditions of vulnerability towards the nature of the physical hazard itself?" (Kelman, 2014, p. 120; see also Baldacchino, 2017; Powell et al., 2014; Pugh, 2017).

On the one hand, perhaps it is somewhat inevitable that whilst today there are many critiques of resilience, these nevertheless still tend to stick with resilience itself as a key trope to be recovered, rescued and kept in play. As explained above, the conditions of the Anthropocene foreground how islands exist within vast, complex, multdimensional relations: capitalist, environmental, social, political, geopolitical and otherwise. Yet, on the other hand, given all this rich complexity and potentiality, it is also rather strange that the trope of 
resilience remains so dominant; and that often islands continue to be objectified, even romanticised, through it.

We are all humbled by the Anthropocene; but 'resilience' is not the only logical response or political horizon.

Here then, we island studies scholars have an important role to play; expanding debate creatively beyond what are still too narrow dominant tropes of island life in the Anthropocene. A key concern would be how island studies scholars can work more closely with broader international island networks, extending debate beyond what have become rather reductive tropes of island vulnerability, adaptation and resilience into new political horizons for island networks, which today often span many islands and archipelagos. There is much to be made of these networks. One understands that buzzwords are where the funds and money can be found. But in sticking with confined frameworks of reasoning and impoverished politics, we are also closing down the loop of debate for islands across the globe in the Anthropococene; rather than opening up the range of possibilities of these burgenoning island networks into something more potentially expansive.

\section{Conclusion: the shifting stakes of island studies in the Anthoprocene}

We are now living at a time that is variously called the Anthropocene, where the character of phenomena like global warming place all life within profoundly asymmetrical and humbling situations. The Anthropocene puts islands and archipelagos much more obviously within vastly interweaving multidimensional relations, even as these manifest in locally contingent ways on and within different islands. Variously focusing upon the multiple temporalities of the Anthropocene, island ontology, the transformative logics of new sensing techniques and data machines, and the figure of the indigenous islander, this paper has engaged the wider theme of islands and relationality in the Anthropocene. The aim has been to build positively upon the relational and archipelagic turns in island studies to date, whilst reorientating relationality and islands in new ways. I have also sought, perhaps more controversially, to critique resilient ethics associated with islands in the Anthropcoene, and in particular to trouble how these work to reduce the figure of the island and indigenous subject. The island has become arguably one of the most emblematic figures of the Anthropocene. It is regularly invoked as not only exemplary to the changing stakes of our planet, but of new resilience ethics as well. Island studies scholars are in a good position to engage the theme of relationality and islands in the Anthropocene; to question, trouble and revisit some fundamental debates.

\section{Acknowledgments}

My sincere thanks to Adam Grydehøj and two anomymous referees for their insightful comments on earlier drafts. This paper was presented as a keynote at Negotiating Waters: Seas, Oceans and Passageways in the Colonial and Postcolonial Anglophone World, ILCEA 4-University of Grenoble Alpes \& Memorial University of Newfoundland (MUN), 15-16 February 2018.

\section{References}

Arms Control Association (2017). The Nuclear Testing Tally. Arms Control Association. https://www.armscontrol.org/factsheets/nucleartesttally

Baldacchino, G. (2017). Seizing history: development and non-climate change in Small Island Developing States. International Journal of Climate Change Strategies and Management. https://doi.org/10.1108/IJCCSM-02-2017-0037 
Baldacchino, G. (2006). Islands, island studies, island studies journal. Island Studies Journal, $1(1), 3-18$.

Bennett, J. (2009). Vibrant matter: A political ecology of things. Durham: Duke University Press. https://doi.org/10.1215/9780822391623

Blasdel, A. (2017). 'A reckoning for our species': the philosopher prophet of the Anthropocene. The Guardian, 15 June. https://www.theguardian.com/world/2017/jun/15/timothy-morton-anthropocenephilosopher

Blum, H. (2013). Introduction: oceanic studies. Atlantic Studies, 10(2), 151-155. https://doi.org/10.1080/14788810.2013.785186

Bongie, C. (1998). Islands and exiles: the Creole identities of post/colonial literature. Palo Alto: Stanford University Press.

Brathwaite, E.K. (1999). ConVERSations with Nathaniel Mackey. Staten Island: We Press.

Bratton, B.H. (2016). The Stack: on software and sovereignty. Cambridge MA: MIT press. https://doi.org/10.7551/mitpress/9780262029575.001.0001

Bremner, L. (2016). Thinking architecture with an Indian Ocean aquapelago. GeoHumanities, 2(2), 284-310. https://doi.org/10.1080/2373566X.2016.1234353

Chakrabarty, D. (2009). The climate of history: Four theses. Critical inquiry, 35(2), 197-222. https://doi.org/10.1086/596640

Chandler, D. (forthcoming, 2018). Ontopolitics in the Anthropocene: an introduction to mapping, sensing and hacking. Abingdon: Routledge.

Chander, D., \& Reid, J. (forthcoming, 2018). 'Being in being': contesting the ontopolitics of indigeneity today. European Legacy, 23(1).

Chandler, D. (2017). Securing the Anthropocene? international policy experiments in digital hacktivism: a case study of Jakarta. Security Dialogue, 48(2), 113-130. https://doi.org/10.1177/0967010616677714

Clark, E., \& Tsai, H. M. (2009). Ecologically unequal exchange and landesque capital on Kinmen island. Asia-Pacific Forum, 44(2), 148-167.

Clark, N., \& Yusoff, K. (2017). Geosocial formations and the Anthropocene. Theory, Culture E Society, 34(2-3), 3-23. https://doi.org/10.1177/0263276416688946

Crane, R., \& Fletcher, L. (2017). Island genres, genre islands: conceptualization and representation in popular fiction. Lanham, MD: Rowman and Littlefield.

Davis, S. (2017). Apparatuses of occupation: translocal social movements, states and the archipelagic spatialities of power. Transactions of the Institute of British Geographers, 42(1), 110-122. https://doi.org/10.1111/tran.12152

Danowski, D., \& Viveiros de Castro, E.B. (2016). The ends of the world. Cambridge: Polity.

Dash, M.J. (2006). Farming bones and writing rocks: rethinking a Caribbean poetics of (dis)location. Shibboleths: Journal of Comparative Theory, 1(1), 64-71.

DeLoughrey, E. (2007). Routes and roots: navigating Caribbean and Pacific island literatures. Honolulu: University of Hawaii Press.

DeLoughrey, E. (2001). 'The litany of islands, the rosary of archipelagoes': Caribbean and Pacific archipelagraphy. ARIEL: A Review of International English Literature, 32(1), 21-51.

Depardon, R., \& Virilio, P. (2008). Native land: stop eject. Paris: Fondation Cartier.

Edwards, P.N. (2010). A vast machine: computer models, climate data, and the politics of global warming. Cambridge MA: MIT Press.

Farinelli, M.A. (2017). Island societies and mainland nation-building in the Mediterranean: Sardinia and Corsica in Italian, French and Catalan nationalism. Island Studies Journal, 12(1), 21-34. https://doi.org/10.24043/isj.3

Fletcher, L. (2011). ' ... some distance to go': a critical survey of island studies. New Literatures Review, 47-48, 17-34. 
Farbotko, C., Stratford, E., \& Lazrus, H. (2016). Climate migrants and new identities? the geopolitics of embracing or rejecting mobility. Social \& Cultural Geography, 17(4), 533552. https://doi.org/10.1080/14649365.2015.1089589

Gillis, J.R. (2004). Islands of the mind: how the Western imaginary shaped the Atlantic world. New York: Palgrave Macmillan.

Glissant, É. (1997a). Poetics of relation. Ann Arbor: University of Michigan Press. https://doi.org/10.3998/mpub.10257

Glissant, É. (1997b). Traité du tout-monde. Paris: Gallimard.

Graziadei, D., Hartmann, B., Kinane, I., Riquet, J., \& Samson, B. (2017). On sensing island spaces and the spatial practice of island-making: introducing island poetics, Part I. Island Studies Journal, 12(2), 239-253. https://doi.org/10.24043/isj.28

Grove, K., \& Pugh, J. (2015). Assemblage thinking and participatory development: Potentiality, ethics, biopolitics. Geography Compass, 9(1), 1-13. https://doi.org/10.1111/gec3.12191

Grydehøj, A. (2017). A future of island studies. Island Studies Journal, 12(1), 3-16. https://doi.org/10.24043/isj.1

Grydehøj, A., \& Hayward, P. (2014). Social and economic effects of spatial distribution in island communities: Comparing the Isles of Scilly and Isle of Wight, UK. Journal of Marine and Island Cultures, 3(1), 9-19. https://doi.org/10.1016/j.imic.2014.03.002

Grydehøj, A., Pinya, X. B., Cooke, G., Doratll, N., Elewa, A., Kelman, I., Pugh, J., Schick, L., \& Swaminathan, R. (2015). Returning from the horizon: introducing Urban Island Studies. Urban Island Studies, 1, 1-19. https://doi.org/10.20958/uis.2015.1

Giusti-Cordero, J. (2017). In Puerto Rico, we invented resilience, New York Times, 24 October. https://mobile.nytimes.com/2017/10/24/opinion/puerto-rico-hurricaneresilience.html?smid=tw-share\&referer=https://t.co/Q94WfC9gzR?amp=1

Hay, P. (2006). A phenomenology of islands. Island Studies Journal, 1(1), 19-42.

Hayakawa. R. (2016). Self-determination for the communication policy in the Pacific Islands. In M. Ishihara, E. Hoshino, \& Y. Fujita (Eds.), Self-determinable development of small islands (pp. 179-202). Tokyo, Japan: Springer. https://doi.org/10.1007/978-981-10$\underline{0132-1 \quad 10}$

Hayward, P. (2018) Keynote: Formulations in flux. Archipelagos and Aquapelagos Conceptualising Islands and Marine Spaces conference, Pratt Institute, Brooklyn, 30 March-1 April.

Hayward, P. (2012b) Aquapelagos and aquapelagic assemblages. Shima, 6(1), 1-11.

Hayward, P. (2012b). The constitution of assemblages and the aquapelagality of Haida Gwaii. Shima, 6(2), 1-8.

Hau'ofa, E. (2008) We are the ocean. Honolulu: University of Hawai'i Press.

Hidalgo, C., Ther, F., Saavedra, G., \& Díaz, A. (2015). Affordance of landscapes and economic socio-spatial networks in the Quinchao archipelago, Chile: a contribution to landscape research and island studies. Island Studies Journal, 10(1), 49-70.

Hong, G. (2017). Locating Zhuhai between land and sea: a relational production of Zhuhai, China, as an island city. Island Studies Journal, 12 (2), 7-24. https://doi.org/10.24043/isj.16

Karampela, S., Papazoglou, C., Kizos, T., \& Spilanis, I. (2017). Sustainable local development on Aegean islands: a meta-analysis of the literature. Island Studies Journal, 12(1), 71-94. https://doi.org/10.24043/isj.6

Kearns, R., \& Collins, D. (2016). Aotearoa's archipelago: re-imagining New Zealand's island geographies. New Zealand Geographer, 72(3), 165-168. https://doi.org/10.1111/nzg.12140

Kelman, I. (2014). No change from climate change: vulnerability and small island developing states. The Geographical Journal, 180(2), 120-129. https://doi.org/10.1111/geoj.12019 
Korson, C. (2017). Framing social rebalancing, national identity, and victimhood in Kanaky/New Caledonia. Social \& Cultural Geography, forthcoming. https://doi.org/10.1080/14649365.2017.1286372

Lee, S.H., Huang, W.H., \& Grydehøj, A. (2017). Relational geography of a border island: local development and compensatory destruction on Lieyu, Taiwan. Island Studies Journal, 12(2), 97-112. https://doi.org/10.24043/isj.33

Lewis, S.L., \& Maslin, M.A. (2015). Defining the Anthropocene. Nature, 519(7542), 171180. https://doi.org/10.1038/nature14258

Luo, B., \& Grydehøj, A. (2017). Sacred islands and island symbolism in ancient and imperial China: an exercise in decolonial island studies. Island Studies Journal, 12(2), 25-44. https://doi.org/10.24043/isj.19

Martínez-San Miguel, Y. (2014) Coloniality of diasporas: rethinking intra-colonial migrations in a pan-Caribbean context. New York: Palgrave Macmillan.

Morton, T. (2016). Molten Entities. In D. Daou \& P. Pérez-Ramos (Eds.) New Geographies 08: Island (pp. 72-76). Cambirdge, MA: Universal Wilde.

Morton, T. (2013). Hyperobjects: philosophy and ecology after the end of the world, Minneapolis: University of Minnesota Press.

Morton, T. (2012). Ecology without the present. Oxford Literary Review, 34(2), 229-238. https://doi.org/10.3366/olr.2012.0043

Mountz, A. (2015). Political geography II: islands and archipelagos. Progress in Human Geography, 39(5), 636-646. https://doi.org/10.1177/0309132514560958

Mycoo, M.A. (2017). A Caribbean new urban agenda post-habitat III: closing the gaps. Habitat International, 69, 68-77. https://doi.org/10.1016/j.habitatint.2017.09.001

Nadarajah, Y., \& Grydehøj, A. (2016). Island decolonization: island studies as a decolonial project. Island Studies Journal, 11(2), 437-446.

Nakashima, D. McLean, C.G. Thulstrup, H. Castillo, A.M. \& Rubis, J. (2012). Weathering uncertainty: traditional knowledge for climate change assessment and adaptation. Paris: UNESCO.

Nola Defender (2015). DON'T CALL ME RESILIENT. Nola Defender, 28 August. http://www.noladefender.com/content/dont-call-me-resilient

Okihiro, G.Y. (2010). Unsettling the imperial sciences. Environment and Planning D: Society and Space, 28(5), 745-758. https://doi.org/10.1068/d7210

Papetti, F. (2017). Capitalist floods in the Pacific Islands. Entitle Blog, 11 December. https://entitleblog.org/2017/12/11/capitalist-floods-in-the-pacific-islands/

Parry, M.L. Canziani, O.F. Palutikof, J.P van der Linden, P.J., \& Hanson, C.E. (Eds.) (2007). Contribution of Working Group II to the Fourth Assessment Report of the Intergovernmental Panel on Climate Change, 2007. Cambridge, Cambridge University Press.

Peta Jakarta (2018). Peta Jakarta. https://theodi.org/odi-showcase-peta-jakarta-real-time-floodmapping-jakarta

Papoutsaki, E., Cass, P., \& Matbob, P. (2016). Old and new media in the Pacific Islands: synergies, challenges and potential. Paper presented at International Association for Media and Communication Research (IAMCR) Conference, University of Leicester, UK.

Povinelli, E.A. (2016). Geontologies: a requiem to late liberalism. Durham, NC: Duke University Press. https://doi.org/10.1215/9780822373810

Powell, N.S., Larsen, R.K., \& van Bommel, S. (2014). Meeting the 'Anthropocene' in the context of intractability and complexity: infusing resilience narratives with $\begin{array}{lll}\text { intersubjectivity. } & \text { Resilience, } & \text { 135-150. }\end{array}$ https://doi.org/10.1080/21693293.2014.948324

Pugh J., \& Grove, K. (2017). Assemblage, transversality and participation in the neoliberal university. Environment and Planning D, 35(6), 1134-1152. https://doi.org/10.1177/0263775817709478 
Pugh, J. (2017). Postcolonial development, (non)sovereignty and affect: living on in the wake of Caribbean political independence. Antipode, 49(4), 867-882. https://doi.org/10.1111/anti.12305

Pugh, J. (2016). The relational turn in island geographies: bringing together island, sea and ship relations and the case of the Landship. Social \& Cultural Geography, 17(8), 10401059. https://doi.org/10.1080/14649365.2016.1147064

Pugh, J. (2014). Resilience, complexity and post-liberalism. Area, 46(3), 313-319. https://doi.org/10.1111/area.12118

Pugh, J. (2013a). Island movements: thinking with the archipelago. Island Studies Journal, 8(1), 9-24.

Pugh, J. (2013b). Speaking without voice: participatory planning, acknowledgment, and latent subjectivity in Barbados. Annals of the Association of American Geographers, 103(5), 1266-1281. https://doi.org/10.1080/00045608.2012.706571

Pugh, J. (2005). The disciplinary effects of communicative planning in Soufriere, St Lucia: governmentality, hegemony and space-time-politics. Transactions of the Institute of British Geographers, 30(3), 307-321. https://doi.org/10.1111/j.1475-5661.2005.00173.x

Pugh, J., Thien, D., Marres, N., Featherstone, D., Griffin, L., Banerjee-Guha, S., ... \& Brown, J. (2009). What are the consequences of the 'spatial turn' for how we understand politics today? A proposed research agenda. Progress in Human Geography, 33(5), 579-586. https://doi.org/10.1177/0309132508099795

Ratter, B.M.W. (2012). Complexity and emergence. In M. Glaser, G. Krause, B.M.W. Ratter, \& M. Welp (Eds.) Human-nature interactions in the anthropocene: potentials of socialecological systems analysis (pp. 83-101). Abingdon: Routledge.

Rankin, J.R. (2016). Tracing archipelagic connections through mainland islands. New Zealand Geographer, 72(3), 205-215. https://doi.org/10.1111/nzg.12138

Rankin, J.R., \& Collins, F.L. (2017). Enclosing difference and disruption: assemblage, heterotopia and the cruise ship. Social \& Cultural Geography, 18(2), 224-244. https://doi.org/10.1080/14649365.2016.1171389

Redd, D. (2017). Towards an archipelagraphic literary methodology: reading the archipelago in Julieta Campos' The Fear of Losing Eurydice. Island Studies Journal, 12(2), 303-316. https://doi.org/10.24043/isj.37

Reid, J. (2017). 'We the resilient': colonizing indigeneity in the era of Trump. Institute for Interdisciplinary Research into the Anthropocene, 10 November. https://iiraorg.com/2017/10/11/we-the-resilient-colonizing-indigeneity-in-the-eraof-trump/amp/

Riquet, J. (2016). Islands erased by snow and ice: approaching the spatial philosophy of cold water island imaginaries. Island Studies Journal, 11(1), 145-160.

Roberts, B.R., \& Stephens, M. (2013). Archipelagic American studies and the Caribbean. Journal of Transnational American Studies, 5(1), 1-20.

Roberts, B.R., \& Stephens, M. (Eds.) (2017). Archipelagic American studies. Durham, N.C. \& London: Duke University Press.

Sheller, M. (2009). The new Caribbean complexity: mobility systems, tourism and spatial rescaling. Singapore Journal of Tropical Geography, 30(2), 189-203. https://doi.org/10.1111/j.1467-9493.2009.00365.x

Sloterdijk, P. (2009). Spheres theory: talking to myself about the poetics of space. Harvard Design Magazine, 30, 126-137.

Springer, A.S., Turpin, E., Einfeldt, K., \& Wolf, D. (2017). Reverse hallucinations in the archipelago, Intercalations, 3. Berlin: SYNAPSE-The International Curators' Network, K. Verlag \& Haus der Kulturen der Welt.

Steinberg, P.E. (2001). The social construction of the ocean. London: Cambridge University Press. 
Steinberg, P., \& Kristoffersen, B. (2017). 'The ice edge is lost... nature moved it': mapping ice as state practice in the Canadian and Norwegian North. Transactions of the Institute of British Geographers.

Steinberg, P., \& Peters, K. (2015). Wet ontologies, fluid spaces: giving depth to volume through oceanic thinking. Environment and Planning D, 33(2), 247-264. https://doi.org/10.1068/d14148p

Stengers, I. (2015). In catastrophic times: resisting the coming barbarism. London: Open Humanities Press.

Stratford, E. (Ed.). (2016). Island geographies: essays and conversations. London: Taylor \& Francis.

Stratford, E. (2003). Flows and boundaries: small island discourses and the challenge of sustainability, community and local environments. Local Environment, 8(5), 495-499. https://doi.org/10.1080/1354983032000143653

Stratford, E., Baldacchino, G., McMahon, E., Farbotko, C., \& Harwood, A. (2011) Envisioning the archipelago. Island Studies Journal, 6(2), 113-130.

Tsai, H.M. (2003). Island biocultural assemblages: the case of kinmen island. Geografiska Annaler: Series B, 85(4), 209-218. https://doi.org/10.1111/j.0435-3684.2003.00143.x

Teaiwa, K.M. (2014). Consuming Ocean Island: stories of people and phosphate from Banaba. Indiana: Indiana University Press.

United Nations Framework Convention on Climate Change (2010). Report of the Conference of the Parties on its sixteenth session, held in Cancun from 29 November to 10 December 2010.

Vaitis, M., Kopsachilis, V., Papapanos, G., Simos, D., Koukourouvli, N., \& Karampela, S. (2017). Supporting island research and development through the 'Archipelago' information system. Island Studies Journal, 12(1), 95-114. https://doi.org/10.24043/isj.7

Verlaan, D. (2016). Life of islands: Maldives in the Anthropocene. Master's thesis, Faculty of Social and Behavioural Sciences Theses, Utrecht University Repository. https://dspace.library.uu.nl/handle/1874/339254

Welcome to the Anthropocene (2017). Welcome to the Anthropocene. http://www.anthropocene.info

Whyte, A.V. (2017). Preparing for the next Hurricane Irma, or Harvey: how analytics and smart cities will help, Huffington Post, 7 November. https://www.huffingtonpost.com/entry/preparing-for-the-next-hurricane-irma-orharvey-how us 5a01cb19e4b085d72ae06d2b

Zalasiewicz, J., Waters, C.N., Williams, M., Barnosky, A.D., Cearreta, A., Crutzen, P., Ellis, E., Ellis, M.A., Fairchild, I.J., Grinevald, J. \& Haff, P.K., 2015. When did the Anthropocene begin? a mid-twentieth century boundary level is stratigraphically optimal. Quaternary International, 383,

196-203. https://doi.org/10.1016/j.quaint.2014.11.045 